\title{
Madeira embroidery: A failed collective brand (1935-59)
}

\section{Maria Benedita Almada Câmara}

To cite this article: Maria Benedita Almada Câmara (2011) Madeira embroidery: A failed collective brand (1935-59), Business History, 53:4, 583-599, DOI: 10.1080/00076791.2011.574693

To link to this article: https://doi.org/10.1080/00076791.2011.574693

曲 Published online: 27 Jul 2011.

Submit your article to this journal $\pi$

Шll Article views: 179

Q View related articles $₫$

4 Citing articles: 2 View citing articles 


\title{
Madeira embroidery: A failed collective brand (1935-59)
}

\author{
Maria Benedita Almada Câmara* \\ Department of Management and Economy and Research Center for Applied Economics of the \\ Atlantic, University of Madeira, Funchal, Madeira Island, Portugal
}

\begin{abstract}
The regional cluster of the Madeira embroidery sector in the political context of 1935 to 1959 provides the basis for an analysis of a common strategy aimed at strengthening the business competitiveness of the industry. The strategy was a government initiative aimed at improving the material welfare of workers and based on the creation of a collective brand. The aim of this paper is to show that the mixed corporatist organisation that managed the initiative was an example of hybrid governance and that the strategy failed because the regulations introduced were not successful in transforming a weak cluster into a strong one. As a result, competition was kept within a circle of low-wage production centres that left Madeira at a disadvantage.
\end{abstract}

Keywords: brand; protected denomination of origin (PDO); cluster; hybrid; competitiveness; regulation; corporatism; trust; embeddedness; coordination; free-riding; certification system

\section{Introduction}

Embroidery in Madeira was a traditional activity that benefited from a protectionist policy after 1926 and was regulated by corporatist rules after 1935. At that time, a common strategy was developed for strengthening the business competitiveness of a cluster of export-oriented craft production firms. This entailed creating a quality certification system and a collective brand. ${ }^{1}$ The corporatist rules implemented between 1935 and 1959 resulted in an excess of regulation which inhibited firms from innovating and competing.

The analysis of the regulatory action of a corporate organisation (a guild composed of representatives of private companies and a government representative), entrusted with the management of a collective brand in an embroidery production cluster reveals a new facet for the empirical study of how hybrid governance structures deal with the mechanisms of cooperation and competition.

Based on transaction cost economics, the work of Ronald Coase (1937/1993), indicates that the limits of market mechanisms require the coordination of certain activities by firms or other organisations. In particular, his inference that bureaucratic arrangements promoted efficiency in hazardous environments led neo-institutional economics to emphasise the dichotomies between markets and

\footnotetext{
*Email: bccamara@uma.pt 
firms. Williamson (1991b) developed this approach allowing for certain kinds of hybrid structures between the dichotomy of markets and hierarchies.

The Madeira embroidery trade always presupposes an inherent volatility regarding a product that is subject to the whims of fashion. On the eve of World War I, the cluster's production and export were dominated by a small number of businesses owned by Germans who shared information and knowledge about the functioning of overseas markets (Câmara, 1998). Between 1917 and 1924, the economic climate underwent a series of rapid changes: a new foreign market, increased demand and a high rate of company start-ups and closures. Between 1924 and the late 1930s stock accumulation and falling prices followed by a prolonged contraction of demand (Boletim de Trabalho, 1930, no. 136) made it difficult for individual companies to bear the volatility costs involved in this type of business.

A return to efficient trading implies going back to a system of mutual bilateral support (Williamson, 1994). In the case of groups of small businesses concentrated in a specific location, it is necessary to determine whether the emergence of cooperation processes was inevitable. On the other hand, studies of the interaction between economic agents within industrial districts detected policing by local institutions in addition to the operation of accepted codes of conduct (Sabel \& Zeitlin, 1985). Another example was the use of a transaction costs approach to analyse the operation of a specific cluster. This emphasises the capacity of small firms to take strategic decisions to cooperate and to set up governance structures (such as business associations) other than markets with the aim of facilitating the building of relations based on trust and the sharing of knowledge among agents that were also competing with each other (Carnevali, 2004, p. 537). ${ }^{2}$

In this case, the role of coordination fell to the Guild. This organisation served as a 'rule-maker' and 'referee', but was not a 'player' (Duguid \& Lopes, 1999, p. 88; North, 1991, p. 1). It operated as a hybrid governance structure involving some forms of hierarchical relationships (Ménard, 2006) and coordinated interim decisions on how to make the 'Madeira embroidery' collective brand created by the government a viable concept. ${ }^{3}$

The theoretical debate in economics concerning private and collective brands has clarified the difference between their respective functions. The use of collective brands can be explained in terms of both a scale-driven approach and a productdriven approach. The latter approach is not suitable for the Madeira embroidery sector. In spite of this, the paper analyses the motives for introducing a collective brand based on the concept of a Protected Denomination of Origin (PDO). ${ }^{4}$

The theme of cluster dynamics in relation to the performance of the regions where they are located was analysed by Porter (1998). We shall consider the characteristics and evolution of the competitive advantages of the Madeira economy between 1935 and 1958 following the decision to create a collective brand.

This article is structured in five sections. Following the introduction, the second section outlines the part played by embroidery in the Madeira economy, describes the evolution of exports and competitors, and presents the main aspects of Portuguese regulation of a weak cluster. The third section presents the theoretical debate regarding private and collective brands to show that the government initiated and guided a common strategy aimed at stabilising the embroidery market and improving the welfare of workers by creating a collective brand based on a PDO system. The fourth section describes the role of the hybrid governance structure. Finally, section five sets out the main conclusions: that the application of corporatist 
rules to the embroidery cluster between 1935 and 1959 caused inefficiency and that the collective brand was a failure.

\section{Context}

\subsection{Embroidery and the Madeira economy}

Production in Madeira developed at the same time as the international process of embroidery mechanisation. Following mechanisation, neither the embroidery nor lace industries evolved in a straightforward manner. Highly volatile fashion trends created an opportunity for the hand embroidery and the handmade lace industries. There were different markets for both types of production and design was always a matter of excellence for both products (Levey, 1983). Madeira embroidery followed the typical path of a craft industry that replaces undifferentiated production by diversifying finished products.

In Madeira, the bulk of production came from embroiderers working at home (outworkers). The difference in pay between these outworkers and workers employed in the workshops was extremely large. In 1939, female cutters (the lowest-paid job) working in workshops earned five escudos a day, compared with one escudo a day for an outworker doing the same job. ${ }^{5}$ Improving the welfare of the outwork embroiderers was one of the priorities of the regulators.

Up to 1960, Madeira had an agricultural economy based on intensive work, which absorbed $50 \%$ of its workforce. Embroidery remained labour-intensive in nature, but we cannot conclude from the data that the ratio of manpower increased in relation to the amount of textiles used by the industry (Indústria, 1958, p. 17; Rodrigues, 1955, p. 135).

In 1952 , it was estimated that embroidery supported $50 \%$ of the population. In that year, the value generated by embroiderer outworkers was 47,252 contos. This was higher than the value generated in 1948 by any of Madeira's principal commercial crops: bananas, sugar cane, or wine (respectively $17 \%, 10 \%$ and $13 \%$ of 220,329 contos, the estimated total value of agricultural production). ${ }^{6}$

Our study ends two years before Portugal joined the European Free Trade Association (EFTA) (1960), the year in which the Board of Guild registered that the Madeira embroidery industry was suffering from competition with producing countries where wages were lower than in Madeira (Indústria, 1958, p. 11). This was despite the fact that between 1937 and 1959 embroidery accounted for more than $60 \%$ of Madeira's total exports, in value terms, and that in 1964 embroidery accounted for $21 \%$ of total industrial production in value terms (Inquérito, 1964).

The economic transformation that occurred in Madeira following its membership of the EEC (1986) lessened the importance of the embroidery industry. In 1994, Madeira embroidery was omitted from an analysis of Portuguese business sectors with competitive potential (Porter, 1994). Currently, some industrial respondents who were interviewed estimate the number of embroiderers at 3000-4000 and the number of embroidery companies regularly producing and exporting at seven to eight (see Tables 1 and 2).

\subsection{Exports and competitors}

On the eve of World War I, the largest percentage of Madeira embroidery was exported to Germany and re-exported to South America (Câmara, 1998). Between 
Table 1. Evolution of the number of domestic embroideresses and percentage of embroideresses within the overall number of working women.

\begin{tabular}{lccc}
\hline Years & A. Embroideress (number) & $\begin{array}{c}\text { B. Women aged between } \\
11 \text { and 59 years }\end{array}$ & Embroideress - B (\%) \\
\hline 1863 & 1029 & 48,211 & \\
1906 & 32,000 & 58,543 & $66.37 \mathrm{a})$ \\
1911 & 35,000 & 65,221 & $59.78 \mathrm{~b})$ \\
1914 & 50,000 & & $76.66 \mathrm{c})$ \\
1918 & 48,500 & 74,370 & \\
1923 & 20,000 & 81,447 & $15.43 \mathrm{~d})$ \\
1930 & 58,700 & 97,572 & $59.95 \mathrm{e})$ \\
1937 & 97,899 & \\
1957 & & 97, &
\end{tabular}

Notes: a) 1900 census; b) 1911 census; c) 1920 census with number of embroideresses in 1918 at 50,000; d) 1940 census, with 20,000 embroideresses estimated as being employed full-time in 1937; e) 1960 census with number of embroideresses in 1957.

Sources: Recenseamentos da Populacão (1900-60); Câmara (1998, p. 456); Boletim de Trabalho (1907, 7, p. 15; 1923, 119, p.162, 1927, 128, p.169); Banco de Portugal, Relatório, Balanço (1921, 1922, 1945, 1946); Decree-Law no. 25:643, Diário do Governo, $1^{\text {a }}$ serie, no. 166, 20 July 1935; Minutes of the Board of Directors, 08-02-1937; Indústria, 1958, pp. 13-14.

Table 2. Total number of firms (A), percentage of Portuguese firms (B) and hierarchy of the firms (C) in $1938(\mathrm{C} 1)$ and in $1952(\mathrm{C} 2)$.

(C)

\begin{tabular}{|c|c|c|c|}
\hline \multicolumn{2}{|r|}{ (C1) } & \multicolumn{2}{|c|}{$(\mathrm{C} 2)$} \\
\hline $\begin{array}{l}\text { (D) Firm's } \\
\text { number } \\
\text { of votes }\end{array}$ & $\begin{array}{l}\text { Number of firms } \\
\text { according } \\
\text { to their (D) } \\
\text { (A in 1938) }\end{array}$ & $\begin{array}{c}\text { (E) Exports } \\
\text { values } \\
\text { (unit }=\text { contos) }\end{array}$ & $\begin{array}{l}\text { Percentage of the } \\
\text { number of export } \\
\text { firms according to } \\
\text { their (E) in } 1952\end{array}$ \\
\hline $1-2$ & 61.3 & 7,150 & 12 \\
\hline $3-5$ & 22.6 & 2,221 & 25 \\
\hline $5-6$ & 9.3 & 650 & 37 \\
\hline $7-8$ & 10.6 & 150 & 26 \\
\hline
\end{tabular}

Notes: The hierarchy of firms $(\mathrm{C})$ is based on export value. $\mathrm{C} 1$ concerns to the number of votes according to the annual value of exports and $\mathrm{C} 2$ expresses the value of exports.

Sources: Anuário Comercial (1913-24); Diário do Governo (1939, p. 403); Rodrigues (1955, p. 140).

1917 and 1924 the focus of trade shifted to the US (between $80 \%$ and $90 \%$ ). This trend continued until 1959 (when the US share of exports was 67\%).

Exports grew strongly between 1917 and 1924 due to the recovery of markets after the war. The fact that the Portuguese currency also underwent a depreciation at this time (a trend that was reversed in 1924) made Portuguese exports relatively cheaper in international markets. In addition to these two fundamental developments, the fact that Asian production centres had not recovered sufficiently to begin supplying their traditional markets immediately after the war was also an advantage for Portugal (Rodrigues, 1955, p. 135). This period of expansion was followed by a fall in exports, which lasted until the 1930s (see Figure 1 and Table 3). As a result, the percentage of the population of 


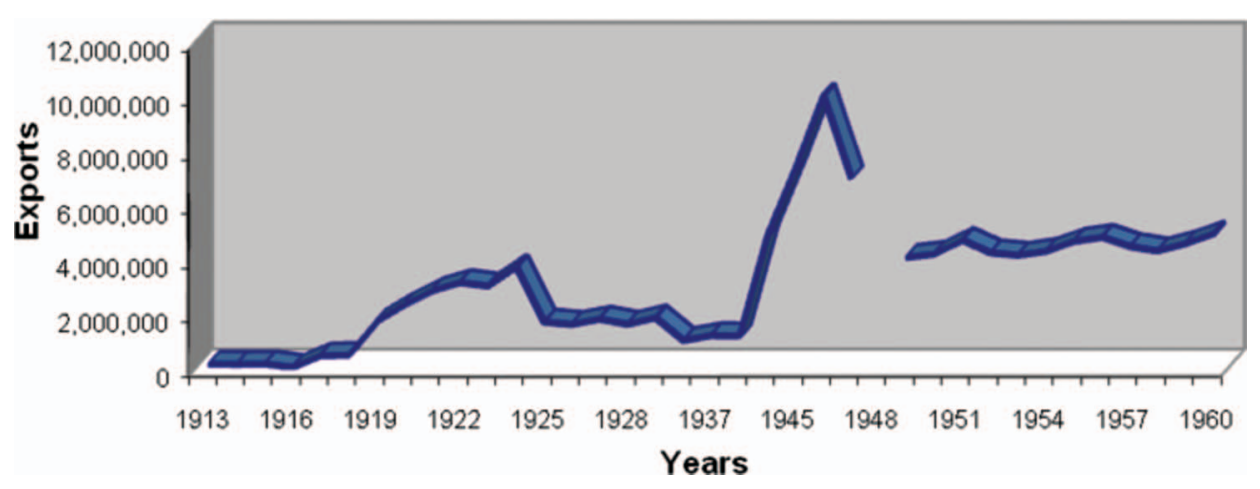

Figure 1. Value of exports of madeira embrodery in current prices (\$).

Sources: See Table 3.

Table 3. Exports value of embroidery of Madeira in current prices (dollars).

\begin{tabular}{lccc}
\hline Average between the years & Exports value & Average between the years & Exports value \\
\hline $1910-16$ & 141,943 & $1937-38$ & $1,185,719$ \\
$1917-24$ & $2,205,141$ & $1944-47$ & $7,317,326$ \\
$1925-30$ & $1,589,513$ & $1949-59$ & $4,401,486$ \\
\hline
\end{tabular}

Note: Consular estimate added $30 \%$ to data of exports to US from 1922 to 1928 and $50 \%$ between 1929 and 1930 .

Sources: British Parliamentary Papers, Consular (1900-14), Miscellaneous Series (1920-21, p. 3), and Great Britain, Department of Overseas Trade (1932, p. 88); Boletim de Trabalho (1913, 75, p. 5; 1929, 136, p. 201); Banco de Portugal, Relatório (1922); Minutes of the Board of Directors, 30-12-1946; Indústria (1958); Anuário Estatístico (1900-36).

working-age women employed as embroiderers in the countryside dropped from $77 \%$ in 1918 to $16 \%$ in 1937 (see Table 1).

Between the two world wars, demand focused on cheap production. The Great Depression aggravated this trend. However, this fails to explain the sharp fall in exports, given that the volume of US imports of Madeira embroidery was very small. From 1924 to 1931, an appreciation of the Portuguese currency (Mateus, 1998, p. 66) made Madeira embroidery uncompetitive in the US market.

Madeira embroidery production was always geared towards exports. ${ }^{7}$ Before World War I, production had emulated the best producers of handmade embroidery (Câmara, 1998). During the period of low demand, the list of competitors included European and Asian countries (the Philippines and China). ${ }^{8}$ Between 1937 and 1959, the market stabilised, given that the value of exports at current prices grew at a rate of $284 \%$. Nevertheless, in 1959 the main competitive threat was concentrated in Asian low-wage, hand-made production centres (Indústria, 1958, p. 11). As a result, Madeira production was left at a disadvantage.

\subsection{Regulation}

Regulation was introduced in 1935 as a continuing improvement of a protectionist policy. The government intended to correct the inability of companies to provide appropriate information to customers about their products by creating a collective brand and a certification system managed by the Guild. This model of social 
regulation was underpinned by the economic regulation that established entry controls. The aim was to prevent excessive competition by making it possible to limit supply. This would supposedly lead to higher prices and make it possible to pay embroiderers better wages (Posner, 1974; Ullen, 2003).

The system of entry controls had a negative impact on individuals who allegedly produced poor quality embroidery. Only firms with a workshop and specialised workers were accredited by the government. This incentive was incorporated into the legislation regarding certification, which would in practice guarantee the elimination of individual producers. It took from 1935 to 1939 to approve the legislation as the minister involved had made it conditional on a revision of the table of minimum prices for embroiderers, which entrepreneurs systematically resisted. ${ }^{9}$ The government representative on the executive board and the board of the general assembly of the Guild had the power - by using a veto - to ensure that the regulations of the guild complied with government policy guidelines, namely in regard to labour issues. ${ }^{10}$

Portugal's corporatist regime saw the market as the basic form of organisation. There were limits to state intervention in the private economy, but cooperation was engineered by the state to minimise excessive competition (Confraria, 2005, pp. 397398). Portuguese economic historians of this period adopt two contrasting approaches. One presents the government as a supporter of private interests (Rosas, 1986, p. 124; Scmitter, 1975, pp. 104, 122, 166-172); the other points out that corporatist organisations were an important factor in demonstrating the power of the state and preventing social breakdown (Garrido, 2004, pp. 135-137). We share the latter view as an explanation of the type of state intervention made in the Madeira embroidery sector.

As a compulsory guild (for anyone exercising a professional activity in the sector), the Guild belonged to a highly selective category created within the Portuguese corporatist regime. It was normally used only in vulnerable export and protected sectors (Garrido, 2004, pp. 170-171). These conditions predisposed the embroidery sector to be guided, organised and disciplined by a Guild.

Private firms played a key role in the Guild's general assembly by negotiating the rules that governed members. ${ }^{11}$ The assembly determined which cloth should be used in the manufacture of each type of product, the cloths that should be covered by tax exemption, the overheads of the industrialists, the prices for each kind of product sold by wholesalers and retailers and the minimum prices for the work of embroiders. Firms within the general assembly agreed on quality standards and established prices and trade commercialisation rules for local and export markets.

In 1935, the voting system of this assembly was one firm, one vote, but this was changed three years later to give priority to the value of exports of each firm. Instead of the amount of manpower contracted each year, product quality, as expressed by its value, became the main criteria. This led to the companies with the largest export capacity dominating the votes. ${ }^{12}$ This change resulted in an evolution towards a market approach, which was also reflected in the internal organisation of the general assembly, which was based on the commissions charged on trade with different geographical markets.

The management board supervised a group of inspectors, which enforced the rules created by the general assembly. Invoices had to follow commercial rules scrupulously, otherwise fines were levied. Inspectors also verified the quality of the embroidery produced. Designs were registered at the Guild to protect the property 
right of the designer of the company that had acquired them. Any company that failed to respect these rights was penalised. ${ }^{13}$

By imposing these rules and entry controls, the Guild failed to promote innovation, particularly in design. Initially, it required all companies to have staff designers, but soon abandoned this rule. It later tried to improve this situation, not by creating incentives that would encourage companies to compete in terms of innovation, but by hiring professionals to guide them. ${ }^{14}$ In 1950, the Board of the Guild demonstrated that it was aware "that one of the reasons which led to a declining interest in the acquisition of women's under and outerwear was the lack of ... skilled staff' who could satisfy 'the demands of fashion'. To resolve this situation, they indicated their willingness to 'set up a workshop for the creation of styles', which could be sold to industrialists. ${ }^{15}$ Regulation was limited to minimising competition and thus inhibited firms from innovating and competing.

\subsection{Cluster framework}

In 1916, a large number of German companies were sold to Americans. From 1916 to 1924 , the number of firms entering the market increased, but a large majority of the firms with workshops were from the US. Some of these firms were subsidiaries of New York companies, which would appear to be in accordance with Mira Wilkins' description of US foreign investment in the embroidery sector in the Philippines, where small firms belonging to citizens with limited amounts of capital invested with a view to taking advantage of low wages (Wilkins, 1974). After 1924, the majority of US firms left Madeira. ${ }^{16}$

In regard to protectionism measures, 29 new local firms entered the market between 1926 and 1935. ${ }^{17}$ In 1935 entry controls were established and only 88 firms were accredited by the government. According to the available data, between 1936 and 1952 - an export boom in the 1940s was responsible for a wave of new entries - the estimated number of entries was 46; exits totalled $20^{18}$ (see Table 2). The structure of the industry maintained a pyramid shape, with foreign firms standing out at the top and with a very large base made up of small firms. Firms differed in their access to credit $^{19}$ and their knowledge of the commercial functioning of export markets. In general terms, regulation promoted the survival of companies of all sizes.

Groupings of small firms in a geographical location can be analysed according to the classic concept of the Marshall Industrial district. From this perspective, firms benefit from external economies of scale to the extent that they become specialised in distinct phases of production (Zeitlin, 2008). Empirical research into this concept has experienced great difficulties in discovering an explanation for the evolution of an industrial district, particularly in regard to what turns a stagnant area into a prosperous one and, on the other hand, what prevents a prosperous area from becoming stagnant.

On the contrary, Michael Porter's diamond analyses cluster performance. He focuses on the evolution of the cluster in relation to the competitive advantages of the own nation or region where the cluster is located. According to this model, the Madeira embroidery industry lacked specialised suppliers and firms in related industries. This was an industry where inputs - fabric and thread - were imported from abroad. Domestic demand was neither segmented nor sophisticated. This not only compromised growth perspectives, but also removed any pressure on firms to 
learn to compete in terms of product differentiation (Porter, 1998). ${ }^{20}$ Bearing this in mind, Madeira constituted a cluster, albeit a weak one.

The vision of the corporatist government did not take into account any positive development in domestic demand. The solution was to base an improvement in the welfare of the embroiderers on increasing prices for overseas consumers as a result of the increased quality achieved by the collective brand. This view assumed that prices rose as a result of the establishment of entry controls to limit competition, and it did not result in embroidery becoming a product characterised by a high elasticity of demand.

\section{Private brands vs. collective brands}

Economic theory shows that private and collective brands have different roles. Trademarks have been seen by neoclassical economics as an obstacle to efficient market functioning as prices are supposed to provide all the necessary information. On the contrary, neo-institutional economics - in accordance with information asymmetry theory, which confers a positive role on reducing transaction costs - sees trademarks as useful tools for improving the working of the market and the circulation of information (Landes \& Posner, 1987). Collective brands were regarded with less enthusiasm than private brands as they were seen as generating rent creation for the producer (Stanziani, 2006) without improving consumer information (Akerlof, 1970).

Quality enforcement problems differ in regard to private and collective brands. The self-enforcement mechanism is peculiar to the private brand because, given the continuous expectation of a price premium, quality is improved and maintained. In this case, the reputation capital of the firm (the actual value of its price premium) is the collateral of the private brand. Private brands are based on self-certification and in this case the state only enforces rights regarding trademarks. ${ }^{21}$ Collective brands can be certified or not by the state. The former approach targets an outside threat such as contra-faction, whereas the latter is aimed at inhibiting fraud and the freeriding behaviour that can emerge within a group (Reynaud, Sauvee, \& Valceschini, 2005; Stanziani, 2007a).

In the case of the Madeira embroidery sector, an attempt was made to create a collective brand that was certified by the Guild. As we will see, the efficiency of this system depended on inhibiting an internal threat arising from potential fraud or freeriding behaviour that could be perpetrated by any member of the group of firms accredited by the government as belonging to the mixed organisation entrusted with the management of the collective brand (the Guild).

Collective brands can be seen from a scale-driven or a product-driven point of view. The first approach focuses on the fact that economic agents need contractual safeguards to invest in sustainable branding strategies. This investment is less likely to be made 'in markets where quality building is spread among many small and scattered producers' (Mazé, 2005, p. 7). James Simpson notes that the business structure in Spain, in the sherry producing region of Cadiz, predominantly made up of large-scale firms, helps explain why legislation on geographically-based collective brands (PDO) for wine was not introduced in this region (Simpson, 2005). In contrast, we argue that in the Madeira embroidery sector the collective brand can be explained in terms of a scale-driven approach. The second, product-driven approach focuses on product typology. Classical typology classifies product characteristics 
(from search, to experience and lastly to credence) according to the evaluation made by consumers before purchase. Agro-food products can be classified in the last two categories of this typology (Darbi \& Karni, 1973). In their case asymmetric information problems may be solved by quality signals. This kind of approach explains why existing PDO systems are associated with agro-food products. The justification is that in their case production inputs such as climate or geological conditions $^{22}$ together with a set of identified technical solutions are considered essential in shaping product characteristics. However, a standardised product is one whose intrinsic characteristics alone are sufficient for consumers to evaluate them. In this sense, embroidery is a standardised product as the characteristics of the product sold to the consumer are based on a price hierarchy.

A PDO rationale prevailed in the Decree of 1935 that regulated the Madeira embroidery sector as it was presented as a system that would provide a guarantee of the origin of the product. The objective of applying the PDO rationale to embroidery was tested in a text that was to be included on export labels. The text defined Madeira embroidery as 'a product hand made by Madeira embroiderers' that benefited from 'protection of origin laws' and involved 'the use of standard words and style' for similar products from other locations. ${ }^{23}$ This means that the use of a PDO classification implied an original and a traditional technical solution.

The transfer of stitches and techniques was common between places dedicated to embroidery or lace. Influences in Madeira embroidery came from first the English, but later became more diversified as a significant proportion of designs were provided by foreign firms when they placed their orders. Accordingly, a pamphlet for the 'Ancor' brand of threads noted that: 'The Madeira needlewoman is an expert in all types of needlework. Even the most primitive embroideries have never had a very definite local character, perhaps because they have always been produced on a large commercial scale'. ${ }^{24}$

This point of view makes it difficult to understand why a government decree would grant a geographical trademark to a non-traditional standardised product such as embroidery. One possible explanation relates to the international debate on trademark protection legislation, which became a major topic during the nineteenth century and the first quarter of the twentieth century. The policing of false claims was scarce before 1883 and trademark protection legislation became the object of several international conventions between 1886 and 1911. The Madrid Convention (1890) outlawed the fraudulent use of place of origin. Common law countries protected reputations associated with the name of a place in the sense of a community right, but such protection is not provided by civil law, which made agreements difficult (Ladar, 1930, pp. 49-50). ${ }^{25}$ In the inter-war period international debates on imposing international norms for selling and producing abroad continued at different levels. Bearing this in mind as well as the efforts made by several local firms to avoid Madeira Wine becoming a generic product, ${ }^{26}$ the origin of the inspiration to improve the competitiveness of embroidery through an attempt to create a geographically related trademark becomes discernable.

\section{The mixed organisation: collective brands and certification system management}

Self-regulation processes, such as the business association, can be implemented in the context of private initiative (Carnevali, 2004). The initiative of introducing 
cooperation mechanisms fell to the government, which approved a decree law creating the guild in 1935. Portuguese corporatist guilds and competition policy have been from the point of view of standard industrial economics. ${ }^{27}$ Our focus is on the role of the embroidery guild as a hybrid governance structure.

Williamson (1991a) defines a hybrid as a specialised form of governance structure for dealing with bilateral dependence. From the moment the government created the collective brand and directed the guild to manage it, an artificial bilateral dependence was created between companies that joined the guild. This became evident in the commitment of companies to produce higher quality goods, making it impossible for any of them to damage the common resource associated with Madeira embroidery as a collective brand (Tirole, 1996; Winfree \& McCluskey, 2005). In order to minimise conflicts, governance structures used a mechanism for selecting partners before the fact, which was set out in the rules for the accreditation of guild members. The monitoring of partners after the fact could involve the application of penalties.

The coordination process in a hybrid structure managing a collective brand can be similar to a hierarchy (Menard, 2004, pp. 356, 366). The general assembly of the Guild operated like a court in determining penalties. The lighter penalties concerned regulations imposed by the government with the aim of creating permanent jobs in the workshops (see Table 4). The heavier sanctions (such as expulsion) were related to the infringement of rules on trading or quality standards (see Table 4). ${ }^{28}$ The weight of the second type of penalty is evidence of the fact that the Guild operated as and had the authority of a hybrid structure for ensuring cooperation between companies and, consequently, for building and maintaining the collective brand.

The combination of autonomy and interdependence between the companies could be considered characteristic of the operation of a hybrid governance structure (Ménard, 2006, p. 31). The Embroidery Guild had no direct business experience abroad. ${ }^{29}$ The Board tried unsuccessfully to create sales offices in New York and Canada to market cheap embroidered products. ${ }^{30}$ Protests were led by the six bigger firms (two were US firms) which had offices in New York, who argued that the Guild was regarded as a regulatory body. The real explanation for this boycott lies in the fact that the power relationships between firms would have been altered. As the embroidery sector was made up of a heterogeneous group of firms, competition between companies centred specifically on the type of products traded in destination markets in terms of marketing expenditure and was not related to price. Firms that

Table 4. Expulsions and fines imposed by the Guild.

\begin{tabular}{|c|c|c|c|c|}
\hline \multirow[b]{2}{*}{ Year } & \multicolumn{3}{|c|}{ Fines (number) } & \multirow{2}{*}{$\begin{array}{c}\text { Expulsions } \\
\text { (number) }\end{array}$} \\
\hline & Total & Work & Sales and receipts & \\
\hline 1936 & & & & 1 \\
\hline 1937 & 3 & 1 & 2 & \\
\hline 1938 & 2 & & 2 & \\
\hline 1939 & 2 & 1 & 1 & 1(a) \\
\hline 1944 & 1 & & $1(\mathrm{~b})$ & \\
\hline 1949 & 1 & & 1 & \\
\hline
\end{tabular}

Notes: a) Disregard of quality rules; b) This fine (disregard of trade rules) was 50 times higher than those related to workplace rules.

Source: Minutes of the Board of Directors. 
were already in business had created a differential advantage in their favour resulting, for example, from preferential agreements with client firms. The boycott was thus a deliberate action taken by established firms against newcomers in a protest that highlights a combination of self-reliance and interdependence.

As a hybrid governance structure, the function of the guild was to reduce transaction costs related to the unpredictability of consumer preferences (Lopes, 1998, pp. 64-69; Williamson, 1991b, 1975). To ensure that the sector could provide consumers with appropriate information, the government created a collective brand. This was based on creating the idea of the existence of specific local qualities - which could not be transferred to another location - including the skill and experience of Madeira embroiderers. Following the implementation of entry controls, the possibility of agents opportunistically providing inappropriate information was eliminated by negotiating mechanisms and the enforcement of the decisions of the general assembly of the Guild.

\section{Conclusion}

In 1935, a collective brand based on the rationale of a PDO system was introduced for the Madeira embroidery industry. This is puzzling because there is no justification for classifying a standardised product in a way that presupposes a link to a terroir. This is accepted nowadays for agro-food products as indications of quality based on geography are seen as having the possibility of enhancing the definition of their characteristics. In addition, the association with a non-existent traditional process also made the label and the brand to which it applied incompatible. No matter what the inspiration was (the battle against Madeira wine becoming a generic product or international debates on imposing international norms on selling and producing abroad), from the point of view of a product-driven approach, embroidery is classified as a standardised product because market prices are considered to play an efficient role in providing information for the consumer.

To address the failures of companies in a weak embroidery cluster in regard to supplying appropriate information about their products, the corporatist regime used the market as an instrument for economic coordination and promoted cooperation to avoid excessive competition. The Embroidery Guild, a mixed corporatist organisation, fulfilled a number of tasks similar to those of a hybrid governance structure, as reflected in the penalties it imposed on its members. However, the form of regulation adopted proved unsuccessful because the collective brand was created for an industry that lacked asset specificity and because entry controls, designed to reduce competition, failed. This was because the embroidery industry is characterised by a high degree of demand elasticity. As a result, increases in the export prices of craft products remained below target.

Between 1935 and 1958, the sector managed to maintain a stable level of employment and to stabilise the market. The certification system effectively controlled the quality of both work and fabrics. The inability of this strategy to achieve the initial goals of economic policy - to improve the material welfare of workers - resulted in its failure. In 1958, the Embroidery Guild's board of directors recognised that the main source of competitive pressure continued to come from those countries paying lower wages than Madeira. From this evidence it can be concluded that regulation was unable to transform a weak cluster into a strong one. Too much regulation inhibited firms from innovating and competing. The 
application of corporatist rules to the embroidery cluster failed to improve efficiency and the creation of a collective brand proved a failure.

\section{Acknowledgements}

I am very grateful to Teresa da Silva Lopes, Ana Maria Evans, Nuno Madureira, Mark Casson, Mathias Kipping, Peter Scott and Paul Duguid for comments and suggestions on earlier versions of this article. I also want to thank two anonymous referees. An earlier version of this paper was presented at the BHC Annual Meetings in June 2006: Toronto, Ontario (University of Toronto) and in the APHES Annual Meeting, Lisbon, Faculdade de Economia da Universidade Nova de Lisboa November 2007. Thank you also to Francesca Carnivali and Mansel Blackford.

\section{Notes}

1. A collective brand is concerned with the relationships - the definition and enforcement of rules - within a group concerned with quality standards, whereas the main concern of a private brand is the identification of rules to protect an asset (Stanziani, 2007b, p. 236 and see n. 23 below).

2. A debate on industrial districts contrasts the embeddedness of a social relations perspective (explained by a cultural disposition among local actors towards trust and cooperation within a closely knit community) with the point of view that sees trust as constructed by governance structures. For the later perspective see Carnivali (2004) and for a critical perspective on this concept drawn from industrial districts in northern Italy in the 1970s and 1980s see Casson $(1999$, p. 6). For the use of embeddedness in linking trust and economic action in two Italian industrial districts see Gaggio (2006). For English examples from a different perspective see Popp (2001, pp. 5-23) and for a review of the literature see Wilson and Popp (2003). For a review of industrial districts literature see Zeitlin (2008). For the embeddedness concept see also Granovetter (1985).

3. In general, there is evidence that brand (collective or private) protection is preceded by tensions (for private brands see Duguid, 2003; and for collective brands see Guy, 1999; Stanziani; 2004). Collective brands through before-the-fact selection create winners and losers and the case of embroidery is no exception.

4. Geography and tradition matters in PDO collective brands (see n. 22 below).

5. Minutes of the Board of Directors, no. 182, 15-05-1939. In 1938, the daily pay for an agricultural worker was 8-10 escudos (Banco de Portugal, Situação Económica da Provincia, 1938). For the corporatist goal of embroidery welfare see Decree-Law no. 25:643, Diário do Governo, $1^{\text {a }}$ serie, no. 166, 20 July 1935 and n. 9 below.

6. Banco de Portugal, Relatório, Balanço (1952); Rodrigues (1955, Vol. 2, p. 136); Sousa (1950, p. 17).

7. In $1958,95 \%$ of total production was exported (Indústria, 1958, p. 8).

8. For European and Asian (namely Philippines and China) competition to Madeira Embroidery see Diário da Manhã, 22 June 1932 and Banco de Portugal report, Relatório, Balanço (1945 and 1946). In 1924, embroidery from the Philippines was negatively affected by the competition in the US market from European embroidery (Commercial handbook, 1926, p. 45).

9. Minutes of the Board of Directors, 23, 19-12-1935; Office letter to the Minister, Minutes of the Board of Directors, no. 161, 10-09-1938; Minutes of the Board of Directors, nos. 168, 16-01-1939; 177, 23-03-1939 and 204, 19-12-1939 and Decree-Law 29:241, Diário do Governo, $1^{\mathrm{a}}$ serie, no. 284, 8 December 1938. In France, the Petain government also tried to make craft professions compatible with aspirations for improved material circumstances without requiring the rationalisation (increased productivity resulting from mechanisation) of production with a view to eliminating economic and social conflicts (Zdatny, 2004, p. 351).

10. The government imposed increased pay rates for embroiderers in outwork against a legislation of the certification system that eliminated industrialists not accredited in 1935 (Minutes of the Board of Directors, no. 118, 18-10-1937).

11. In the eighteenth century, French export quality certification boards ('bureaux de marque') saw regulation as necessary only for high quality products subject to fixed standards and not for fashion products (Minard, 2003, pp. 119-232). This problem is not analysed here. 
12. Decree-Law no. 25:643, Diário do Governo, $1^{\mathrm{a}}$ serie, no. 166, 20 July 1935; Decree-Law no. 29:239, Diário do Governo, $1^{\text {a }}$ serie, no. 284, 8 December 1938; Minutes of the Board of Directors, no. 118, 18-10-1937.

13. Decree 25:643, Diário do Governo, $1^{\mathrm{a}}$ serie, no. 166, 20 July 1935; chapter 1, article 6, c) and h). Registration of designers became compulsory. Many firms were owners or had designs in their possession. If an industrialist used designs registered with the Guild (either the property of a designer or of another company) without due permission, he would also be punished. Firms were in possession of designs because a substantial part of production was ordered by foreign firms. The designs were provided by the foreign firms and local firms, in these cases, simply printed them in different sizes.

14. For the attempt to hire a foreign designer see Minutes of the Board of Directors, no. 547, 28-06-1939 and no. 186, 30-06-1949. The Central Government recommended the use of an English company to provide this type of service, 'Embroidery Design Company Limited' (Minutes of the Board of Directors, 13-12-1952).

15. Minutes of the Board of Directors, no. 592, 08-05-1950.

16. Between 1917 and 1924 there were six firms with head offices in New York. There were two US and one Swiss subsidiary companies in 1938 and one US and one Swiss in 1959. An example of a subsidiary firm was Madeira Embroidery and Co., a branch of Campbell, Chetreger \& Jacobson (Commercial Registration. Livros de Registo, 1917-59 and Minutes 1935-59). For firms that left Madeira after 1924 see: Anuário Comercial (1913-59) and also Commercial Registration of Funchal (1914-50).

17. Data from the Commercial Registration of Funchal (1914-50).

18. Minutes of the Board of Directors, (1936-53).

19. Banco de Portugal, Relatório, Balanço (1921) and Breve (1921).

20. For less developed countries see Ghauri, Lutz, and Tesfom (2003); Ojeda-Gomez, Simpson, Koh, and Padmore (2007) and Rabellotti (1995).

21. For incentives encouraging producers to maintain high quality standards (Klein and Lefflers, 1981; Shapiro, 1983).

22. There is an historical path for the use of quality standards in French wines, namely the PDO. There is a relation between PDO and terroir, but its definition requires an identification of specific characteristics in geological or climatic terms (Stanziani, 2004, 2006, 2007b; and see also Lachiver, 1988, pp. 472-477, 486-506). Recently wine PDOs have faced competition from other international commercial norms (Lopes, 2007, pp. 6-7).

23. Minutes of the Board of Directors, no. 2, 23-08-1935 and no. 8, 23-09-1935. Recently the Portuguese Institute of Industrial Property approved the registration of denomination of origin/geographical indication number 6, Nice Classification number 6 and the registration of the trade mark with a Mix Sign was given the number 255580 (Boletim de Propriedade Industrial, no. 5. 1985 and no. 5, 1991).

24. Traditional embroidery of Portugal [1950s], p. 42.

25. All kinds of association trademarks, whether public or private, were protected in Portugal (Ladar, 1930, p. 586). Association with a place of origin is common. The cutlery and tool industry of Sheffield proved to be unique in campaigning for legislation which protected the city as a 'place of origin from the fraudulent use of its name' (Higgins \& Tweedale, 1995, p. 17). For the role of national trademarks in establishing competitive advantages for certain industries see Higgins and Mordhorst (2008, p. 186).

26. Decree-Law no. 25:643, Diário do Governo, $1^{\text {a }}$ serie, no. 166, 20 July 1935, preamble. See also Tirole (1996); Winfree and McCluskey (2005).

27. For the debate on competition versus collusion see Menard (1996, pp. 176-178) and Raynaud and Valceschini (2005, pp. 165, 195). Organisations managing collective brands have been critically appreciated by economists and economic historians. The analysis of guilds by economic historians is an example of this, but this analysis is being revised. In addition to identifying the origin of products, medieval guilds identified craftsmen until this practice was formally regulated (see Minard, 2003, pp. 119-232, 83-100). Medieval guilds (according to recent studies) and Portugal's corporatist Grémios shared the aim of reducing transactions costs and mitigating conflicts between members (see n. 24). For an explanation of the reason why the state has gradually prevailed as a grantor of collective quality control see Casson (1993/94, p. 6). 
28. Tirole, 1996; Winfree and McCluskey, 2005.

29. Minutes of the Board of Directors, no. 10, 30-09-1935; no. 78, 29-10-1936 and no. 314, 18-12-1942.

30. For commercial interests in the export market of the regulator Companhia do Alto Douro see Duguid and Lopes (1999, pp. 88-89).

31. Minutes of the Board of Directors, no. 44 of 14-04-1936; 15-06-1936; no. 139, 26-031938; no. 208 18-01-1940 and no. 26, 04-01-1935.

\section{Notes on contributor}

Maria Benedita Almada Câmara is Professor of Business History and Economic History at the University of Madeira, Department of Management and Economy, and member of the Centro de Economia Aplicada do Atlântico.

\section{References}

\section{Archives and other sources}

Banco de Portugal

Breve notícia sobre a situação económica, Funchal. (1921).

Relatório, Balanço e Desenvolvimento da Agência do Banco de Portugal do Funchal. (1921, 1922, 1945, 1946).

Commercial Registration of Funchal: Livro de Registo. (1914-50).

Minutes of the Board of Directors of the Guild of the Embroidery of Madeira. (1935-59).

British Parliamentary Papers (Madeira Embroidery references)

Diplomatic and Consular Reports on Trade and Finance. Portugal. Report on Trade of Madeira. Annual Series. 1900, no. 2517, pp. 3-8; 1901 no. 2677, pp. 3-11; 1903, no. 3057, pp. $3-12$; 1904 , no. 3273 , pp. $3-8$; 1905 ; no. 3475 , pp. $3-15$, 1906, no. 3638 , pp. $3-18$; 1907 , no. 3811, pp. 3-165; 1908, no. 4069, pp. 3-14; 1910, no. 4466, pp. 3-16; 1911, no. 4705, pp. 3-13; 1912, no. 4913, pp. 3-13; 1913, no. 5152, pp. 3-13; 1914, no. 5356, pp. 3-13.

Miscellaneos Series. (1920-21). Department of Commerce, Trade of the United States with the world, 115 (Part 1), p. 3.

Great Britain, Department of Overseas Trade. Economic Constitutions in Portugal. (July 1932).

\section{Published sources}

Akerlof, G.A. (1970). The market for lemons: Qualitative uncertainty and the market mechanism. Quarterly Journal of Economics, 84(3), 488-500.

Anuário Comercial de Portugal. (1913-59). Lisboa: Imprensa Nacional.

Anuário Estatístico de Portugal. ([1886]-1936). Lisboa: Ministerio das Obras Publicas, Commercio e Industria, Repartição de Estatística.

Boletim de Propriedade Industrial. (1985-91). Lisboa: Instituto Nacional de Propriedade Industrial.

Boletim de Trabalho Industrial. (1907-30). Lisboa: Imprensa Nacional.

Bond, K. (1994). Design of a novel high-speed embroidery machine, the embroidery of Nottingham (Doctoral dissertation, University of Nottingham). Dissertation Abstracts International (314 AAT C480667 Proquest).

Câmara, B. (1998). A Economia da Madeira (Unpublished doctoral dissertation). Universidade da Madeira, Funchal.

Carnivali, F. (2004). Crooks, thieves, and receivers: Transaction costs in nineteenth-century industrial Birmingham. Economic History Review, 57(3), 533-550.

Casson, M. (1993). Entrepreneurship and business culture. In J. Brown \& M.B. Rose (Eds.), Entrepreneurship networks and modern business (pp. 30-54). Manchester: Manchester University.

Casson, M. (1993/94). Brands: Economic ideology and consumer society (Discussion paper). Department of Economics, University of Reading. 
Casson, M. (1999). Analysing regional business networks: An economic perspective (Discussion paper). Department of Economics, University of Reading.

Casson, M., \& Rose, M.B. (1998). Institutions and the evolution of modern business: Introduction. In M. Casson \& M.B. Rose (Eds.), Institutions and the evolution of modern business (pp. 1-6). London: Routledge.

Coase, R.H. (1937/1993). The nature of the firm. In Oliver E. Williamson \& Sidney G. Winter (Eds.), The nature of the firm. Origins, evolution, and development (pp. 18-33). New York: Oxford University Press.

Coleç̧ão Oficial de Legislação Portuguesa. (1935-39). Lisboa: Imprensa Nacional.

Commercial handbook. (1926). Philippines Carnival Association, [Manila].

Confraria, J. (2005). Politica económica. In P. Lains \& A.F. Silva (Eds.), Historia económica de Portugal (pp. 397-421). Lisboa: Imprensa de Ciências Sociais.

Darbi, M.R., \& Karni, E. (1973). Free competition and the optimal amount of fraud. Journal of Law and Economics, 16(1), 67-86.

Diário da Manhã. (1932). Lisboa.

Diário do Governo. Decree-Law no. 25:643. $1^{\mathrm{a}}$ serie, no. 166, 20 July 1935; Decree-Law no. 29:239. $1^{\text {a }}$ serie, no. 284,8 December 1938; Decree-Law no. 29:241. $1^{\text {a }}$ serie, no. 284,8 December 1938.

Duguid, P. (2003). Developing the brand: The case of alcohol, 1800-1880. Enterprise and Society, 4(3), 405-441.

Duguid, P., \& Lopes T.S. (1999). Ambiguous company: Institutions and organizations in the port wine trade, 1814-1834. Scandinavian Economic History Review, 47(1), 84-102.

Gaggio, D. (2006). Pyramids of trust: Social embeddedness and political culture in two Italian gold jewelry districts. Enterprise and Society, 7(1), 19-58.

Garrido, A. (2004). O Estado Novo e a Campanha do Bacalhau. Lisboa: Círculo do Leitores.

Ghauri, P., Lutz, C., \& Tesfom, G. (2003). Using networks to solve export-marketing problems of small- and medium-sized firms from developing countries. European Journal of Marketing, 37(5/6), 728-752.

Gorman, C.R. (2000). An educated demand: The implications of art in every day life for American industrial design, 1925-1950. Design Issues, 16(3), 45-66.

Granovetter, M. (1985). Economic action and social structure: The problem of embeddedness. American Journal of Sociology, 91(3), 481-510.

Gustafsson, B. (1998). Some theoretical problems of institutional economic history. Scandinavian Economic History Review, 46(2), 5-31.

Guy, K. (1997). Wine, work and wealth: Class relations and modernization in champagne wine industry. Business and Economic History, 26(2), 298-303.

Guy, K. (1999). When Champagne became French: Wine and the making of a national identity. Baltimore: The John Hopkins University Press.

Higgins, D.M., \& Mordhorst, M. (2008). Reputation and export performance: Danish butter exports and the British market, c. 1880-c. 1914. Business History, 50(2), 185-204.

Higgins, D., \& Tweedale, G. (1995). Asset or liability? Trade marks in the Sheffield cutlery and tool trades. Business History, 37(3), 1-27.

Indústria de Bordados da Madeira. Apontamentos. (1958). Funchal: Grémio dos Industriais de Bordados da Madeira.

Inquérito Industrial. (1964). Arquipélago da Madeira. Lisboa: INE.

Klein, B., \& Lefflers, K. (1981). The role of market forces in assuring contractual performance. Journal of Political Economy, 89(4), 615-641.

Lachiver, M. (1988). Vins, vignes et vignerons: Histoire du vignoble Français. Paris: Fayard.

Ladar, S.P. (1930). The industrial protection of industrial property. Cambridge, MA: Harvard University.

Landes, W.L., \& Posner, R.A. (1987). Trade mark law and economic perspective. Journal of Law and Economics, 30(2), 265-309.

Leslie, C.A. (2007). Needlework through history: An encyclopedia. Oxford: Greenwood.

Levey, S.L. (1983). Lace: A history. London: Victoria \& Albert Museum.

Lopes, T.S. (1998). Internacionalização e concentração no Vinho do Porto. 'Cadernos da revista DOURO - Estudos \& Documentos'. Porto: GEHVID/ICEP.

Lopes, T.S. (2007). Global brands. The evolution of multinationals in alcoholic beverages. Cambridge: Cambridge University Press. 
Mateus, A. (1998). Economia Portuguesa (desde 1910) (2nd ed.). Lisboa: Verbo.

Mazé, A. (2005, September). Quality regulation and the creation of a private market for certification: Institutional design and regulatory issues in agro-food. In ISNIE (Ed.), Annual conference of International Society for New Institutional Economics. Barcelona: Pompeu Fabra University. Preliminary draft retrieved from http://www.isnie.org/isnie2005.html

Menard, C. (1995). Markets as institutions versus organizations as markets? Disentangling some fundamental concepts. Journal of Economic Behavior and Organization, 28(2), 161-182.

Menard, C. (1996). On clusters, hybrids and other strange forms: The case of French poultry. Journal of Institutions and Theoretical Economics, 152(1), 154-196.

Menard, C. (2004). The economic of hybrid organization. Journal of Institutional and Theoretical Economics, 160(3), 345-374.

Menard, C. (2006). Hybrid organization of production and distribution. Revista de Analisis Economico, 21(2), 25-51.

Minard, P. (2003). Les bequilles de la confiance dans le secteur textile au XVIIIe siécle. In V. Mangematin \& C. Thuderoz (Eds.), Des mondes de confiance. Un concept à l'épreuve de la réalité sociale (pp. 119-232). Paris: CNRS.

North, D. (1991). Transaction costs, institutions, and economic performance. San Francisco, CA: Institute of Contemporary Studies.

Ojeda-Gomez, J., Simpson, M., Koh, S.C.L., \& Padmore, J. (2007). Achieving competitive advantage in the Mexican footwear industry. Benchmarking: An International Journal, 14(3), 289-305.

Popp, A. (2001). Business structure, business culture and the industrial district. The potteries, $c$. 1850-1914. Aldershot: Ashgate.

Popp, A. (2003). An economic approach to regional business networks. In J.F. Wilson \& A. Popp (Eds.), Industrial clusters and regional business networks in England, 1750-1970 (pp. 19-43). Aldershot: Ashgate.

Porter, M.E (1998). The competitive advantage of nations. Baltimore: Macmillan.

Porter, M. (Ed.). (1994). Monitor company. Construir as vantagens competitivas de Portugal. Lisboa: Fórum para a competitividade.

Posner, R.M. (1974). Theories of economic regulation. The Bell Journal of Economics and Management Science, 5(2), 335-358.

Rabellotti, R. (1995). Is there industrial district model? Footwear districts in Italy and Mexico compared. World Development, 123(1), 29-41.

Recenseamentos da População. (1900-70). Lisboa: Imprensa Nacional.

Reynaud, E., Sauvee, L., \& Valceschini, E. (2005). Alignment between quality enforcement devices and government structure in agro-food vertical chains. Journal of Management and Government, 9(1), 47-77.

Reynaud, E., \& Valceschini, E. (2005). Collectif ou collusif? A propos de l'application du droit des ententes aux certifications officielles de qualité. Revue Internationale de droit Économique, 19(2), 165-195.

Rodrigues, R.H.C. (1955). Questões Económicas (tomo 2). Funchal, Madeira.

Rosas, F. (1986). O estado novo nos anos trinta. Lisboa: Editorial Estampa.

Sabel, C., \& Zeitlin, J. (1985). Historical alternatives to mass-production: Politics, markets and technology in nineteenth-century industrialisation. Past and Present, 108(1), 133-176.

Scmitter, P.C. (1975). Corporatism and public policy in authoritarian Portugal. London: Sage Publications.

Shapiro, C. (1983). Premium, for high quality products as a return to reputation. Quarterly Journal of Economics, 48(4), 659-679.

Simpson, J. (2005). Too little regulation? The British market for sherry, 1840-1890. Business History, 47(3), 367-382.

Sousa, J.I.C. (1950). Estudo Comparativo da Economia da Produção de Banana e Cana Sacarina, Lisboa (Unpublished dissertation). Instituto Superior de Agronomia (ISA).

Stanziani, A. (2004). Wine reputation and quality controls: The origin of the AOCs in the 19th century France. European Journal of Law and Economics, 18(2), 149-167.

Stanziani, A. (2006). Normes, réputation, confiance, marques, marché du vin. Revue de Synthése 5e année 2006 (2), 329-358. 
Stanziani, A. (2007a). Marques, marques collectives. In A. Stanziani (Ed.), Dictionnaire historique d'economie-droit XVIII-XXe sicles (pp. 299-230). Paris: LGDJ.

Stanziani, A. (2007b). A l'origine de appellations d'origine contrôlée. Économie et droit des marques collectives en France au XIXe siècle. In A. Drouard \& J.-P. Williot (Eds.), Histoire des Innovations Alimentaires XIXe e XXe siècles (pp. 165-199). Paris: L'Harmattan.

Tirole, J. (1996). A theory of collective reputation (with applications to the persistence of corruption and firm quality). Review of Economic Studies, 63(1), 1-22.

Traditional embroidery of Portugal. [1950s]. Book no. 1. Portugal: Anchor Embroidery.

Ullen, T.S. (2003). Regulation. In J. Mokyr (Ed.), The Oxford encyclopedia of economic history (pp. 350-360). Oxford: Oxford University Press.

Varley, D.E. (1959). A history of the Midland Counties Association Lace Manufacturer's Association in 1915-1958. Long Eaton: Lace Productions.

Wilkins, M. (1974). The maturing of multinational enterprise: American business abroad from 1914 to 1970. Cambridge, MA: Harvard University Press.

Williamson, O. (1991a). Markets and hierarchies - analysis and antitrust implications. New York: Free Press.

Williamson, O. (1991b). Comparative economic organization: The analysis of discrete structural alternatives. Administrative Science Quarterly, 36, 269-296.

Williamson, O.E. (1994). Transaction cost economics and organization theory. In N.J. Smelser \& R. Swedberg (Eds.), The handbook of economic sociology (pp. 77-107). Princeton, NJ: Princeton University Press.

Wilson, J.F., \& Popp, A. (2003). Districts, networks and clusters in England: An introduction. In J.F. Wilson \& A. Popp (Eds.), Industrial clusters and regional business networks in England, 1750-1970 (pp. 1-18). Aldershot: Ashgate.

Winfree, J.A., \& McCluskey, J.J. (2005). Collective reputation and quality. American Journal of Agricultural Economy, 87(1), 206-213.

Zdatny, S. (2004). Les artisans et le mirage corporatist, 1919-1945. In S.-L. Kaplan \& P. Minard (Eds.), La France Malade du Coporatisme? XVIIIe-XXe siècles (pp. 327-352). Paris: Belin.

Zeitlin, J. (2008). Industrial districts and regional clusters. In G. Jones \& J. Zeitlin (Eds.), The Oxford handbook of business history (pp. 244-267). Oxford: Oxford University Press. 